\title{
"Nieziemsko piękna / we wszechświecie rana” Figura homoseksualisty w wybranych wierszach Tadeusza Różewicza
}

\author{
"An unearthly beautiful wound in the universe" \\ A homosexual figure in selected poems of Tadeusz Różewicz
}

\begin{abstract}
Homosexuality is not the head subject of Tadeusz Różewicz's works, but it is worth to pay attention to the unusual model of masculinity, which he presents especially in the case of gays. The author analyses two Różewicz's poems: Zakatrupiony and Tate Gallery Shop. In these texts high culture art is situated next to the common dirt and 'shit of the world.' This contrast is used to present the main characters' corporeality as problematic and depict their sexuality as stigmatic. Unexpected references to camp aesthetics are adjacent to the turpist ugliness and physiology of death. Różewicz's interest in the social margin, due to the 'pop' tricks like fragment and assembly techniques typical for the fine and visual arts, alludes to the painting and film contexts of poems, as well as to the biographies of the heroes of these texts: Piero Paolo Pasolini and Francis Bacon. It effectively directs the readers' attention to the problems of contemporary world which are important for the poet.
\end{abstract}

Key words: wound, body, homosexuality, camp, aesthetics of ugliness

Streszczenie: Tadeusz Różewicz nie poświęca homoseksualizmowi naczelnego miejsca $w$ swojej twórczości, warto jednak zwrócić uwagę na przewijający się w niej nietypowy model męskości, a zwłaszcza na postaci gejów. Przedmiotem zainteresowania autora będą dwa teksty Różewicza: Zakatrupiony oraz Tate Gallery Shop. W wierszach tych podniosła sztuka sąsiaduje z powszednim brudem i „gównem świata". Zarysowujący się w utworach kontrast sprowadza problem do cielesności bohaterów i ukazuje ich seksualność jako rodzaj piętna. 
Nawiązania do estetyki kampowej nieoczekiwanie sąsiadują tu z turpistyczną brzydotą i fizjologią śmierci. Zainteresowanie Różewicza społecznym marginesem, dzięki zastosowanym „popowym” chwytom: technikom fragmentu i montażu, właściwym sztukom plastycznym i wizualnym, nawiązuje do malarskich i filmowych kontekstów wierszy, a także biografii bohaterów tych tekstów: Piera Paola Pasoliniego i Francisa Bacona, skutecznie zwracając uwage odbiorcy na zajmujące poetę problemy współczesnego świata.

Słowa kluczowe: rana, ciało, homoseksualizm, kamp, estetyka brzydoty

Tadeusz Różewicz w oczach współczesnych badaczy jawi się jako wybitny znawca tradycji europejskiej. Erudycja poety przejawia się w szeroko pojmowanej intertekstualności, której siatka referencji składa się z nieskończonej ilości splotów, tworząc zapożyczenia sięgające daleko do źródeł naszej kultury. Międzytekstowy dialog, w jaki wchodzi autor Niepokoju z innymi sztukami artystycznymi, z szeroko pojętymi utworami, każe dociekać, szukać, włączać się w ten dialog, dyskutować z propozycjami poety. Teksty te służą tworzeniu autorskiego kolażu, budowaniu spójnej całości, asocjacyjnemu łączeniu, które pozwala na nowo odczytywać wykorzystane treści. To łączenie nie polega jedynie na przypominaniu lub przywoływaniu kulturowych „prefabrykatów”: cudzych utworów czy biografii. Tłumaczenie ich treści, jej wykorzystanie, wsparte jest interpretacją, która nadbudowuje nowe znaczenia.

Poetyka pisarstwa Różewicza to „poetyka lektury”, w której mamy do czynienia z pisaniem za pośrednictwem innych tekstów czy wręcz często z "lekturą osoby" odzwierciedloną w tekście 1 . Poeta w swoich dialogach z literaturą i kulturą często sięga po niekonwencjonalną i niepopularną tematykę. Figura Innego, Obcego w kulturze jest dla autora Kartoteki fascynująca m.in. z antropologicznego i socjologicznego punktu widzenia, do czego nawiązała Aleksandra Ubertowska w kontekście inspiracji, jakich dostarczała poecie literatura niemiecka².

Różewicz chętnie rozprawia się z mitami i kompleksami, wydobywając na wierzch to, co najgłębiej skrywane, otwarcie podejmując kwestie stanowiące społeczne tabu. Tak jak interesuje go śmietnik

${ }^{1}$ Por. Z. Majchrowski: Pisarz i jego sobowtór. Rekonesans. W: Autor, podmiot, bohater. Studia. Red. A. Martuszewska, J. SŁawiński. Wrocław 1983, s. 58.

2 Por. A. Unertowska: Tadeusz Różewicz a literatura niemiecka. Kraków 2001, s. 12. 
współczesnej kultury, tak równie frapujący wydają się mu ludzie z marginesu, wyrzutkowie trafiający na śmietnik społeczeństwa wszyscy ci, którzy nie przystają do ogólnie przyjętych norm i w jakiś sposób się od nich dystansują. Najbardziej spopularyzowanym typem „śmietnikowego bohatera” Różewicza są staruszkowie, którzy przede wszystkim fascynują poetę. Nie stroni on jednak również od skrajnie odmiennych motywów, silnie nacechowanych erotycznie, związanych z homoseksualizmem czy prostytucją ${ }^{3}$.

W swoim wywodzie pragnę skupić się na dwóch wyrazistych utworach Różewicza z przełomu lat 70. i 80.: Zakatrupionym z tomu Opowiadanie traumatyczne oraz Tate Gallery Shop ze zbioru Na powierzchni poematu $i$ w środku. Bohaterem pierwszego z wierszy, które będą mnie interesowały w kontekście praktyki przedstawienia homoseksualizmu, jest włoski poeta, pisarz, malarz, scenarzysta, znany przede wszystkim jako reżyser głośnych i kontrowersyjnych filmów, Pier Paolo Pasolini. Susan Sontag określiła go mianem „najbardziej rozpoznawalnej figury, jaka pojawiła się we włoskiej sztuce i literaturze po II wojnie światowej"4 .

Liryk rozpoczyna się drastyczną wizją ciała skatowanego Pasoliniego:

\section{Zakatrupiony \\ deską \\ na śmietniku Pier Paolo \\ próbuje z martwych wstać \\ czołga się}

w stulonych dłoniach niesie

ludzkie krwawe

\footnotetext{
${ }^{3}$ Roli seksualności w poezji Tadeusza Różewicza poświęcony został rozdział książki Jana MARXA, zatytułowany Adwokat mniejszości seksualnych. Zob. IDEM: Adwokat mniejszości seksualnych. W: IDEm: Pomiędzy wieża Babel a wieża z kości stoniowej. O poezji Tadeusza Różewicza. Wrocław 2008, s. 37-83. Tomasz Sikora z kolei pisze wprost o zależności pomiędzy zmarginalizowanymi odmieńcami a figurą śmietnika: „Los odmieńca, odłączonego od »cywilizacyjnej misji« i bez wyrzutów oddanego rozkoszy, nie jest zasadniczo różny od losu niemożliwego do zutylizowania śmiecia. [...] W systemie opartym na binarnych opozycjach, odmieniec strukturalnie należy do szarej strefy niejednoznaczności, podobnie jak odpady, które tkwią niezmiennie pomiędzy pozytywną wartością (tożsamością, użytecznością) a negatywną bezkształtnością. (T. Siкora: Odmieńcy/ śmieci. „Kultura Współczesna” 2007, nr 4, s. 46-48).

${ }^{4}$ Cyt. za: S. Żurowski: Skandalista. Pier Paolo Pasolini. http://art.webesteem. pl/14/pasolini.php [dostęp: 1.07.2020].
} 
przyrodzenie jak pisklę

w gnieździe

przed tron Pana ${ }^{5}$

Różewicz w pierwszej strofie przedstawia trupa artysty zatłuczonego tępym narzędziem, rozkładającego się na śmietniku. Plaża, na której rzeczywiście znaleziono ciało reżysera, faktycznie pokryta była stertą śmieci, wyglądała wręcz jak wysypisko ${ }^{6}$. Przyjaciółka Pasoliniego - Oriana Fallaci, w Liście do Piera Paola, opublikowanym po jego wstrząsającej śmierci, pisze: „Przypominałeś kupę śmieci i dopiero później, kiedy Ci się przyjrzeli z bliska, zauważyli, że to nie były śmiecie, byłeś człowiekiem"7. Użyta do ogłuszenia i zmasakrowania Pasoliniego deska (czy też kij) stanowiła fragment pobliskiego ogrodzenia ${ }^{8}$. Autor Czerwonej rękawiczki z właściwą sobie bezpośredniością umieścił w swoim utworze szczegóły zaczerpnięte najprawdopodobniej z ówczesnej prasy, którą nałogowo czytał, cytując zapewne fragmenty opisów miejsca zdarzenia i relacji złożonych przez oprawce po zatrzymaniu przez policję, upublicznionych w mediach.

W kolejnej strofoidzie poeta odziera bohatera z intymności, wydobywając z opisu wszystkich dotkliwych obrażeń ofiary takie szczegóły, jak zmiażdżone genitalia ${ }^{9}$ - symbol męskości, w tym miejscu

${ }^{5}$ Zob. T. Różewicz: Utwory zebrane. T. 9: Poezja. 3. Wrocław 2006, s. 163. Dalej wszystkie fragmenty wierszy Tadeusza Różewicza cytowane za wydaniem Utworów zebranych (Poezja. 3) opatruję skrótem P III i numerem strony.

${ }^{6}$ Por. J. Minoєajewski: Rzymska komedia, Czyściec, Pieśń V. Kronika nagłej śmierci. http://wyborcza.pl/1,97849,7332859,Rzymska_komedia__Czysciec_Piesn_V.html [dostęp: 1.07.2020].

7 O. Fallaci: Pasolini. Niewygodny człowiek. Wstęp A. Cannavò. Tłum. J. Ugniewska. Warszawa 2018, s. 63. Po tragicznej śmierci Pasoliniego Fallaci wszczęła niezależne śledztwo dziennikarskie, które miało na celu udowodnienie, że zabójstwo reżysera nie było przypadkowe, a odpowiedzialność za zbrodnię ponosi więcej niż jedna skazana w procesie osoba (Giuseppe "Pino" Pelosi). Jej tezy zostały odrzucone, Fallaci skazano na cztery miesiące aresztu w zawieszeniu, spotkał ją również ostracyzm w środowisku zawodowym. Zob. A. Cannavò: Oriana i Pier Paolo, przyjaźń niemożliwa. W: O. Fallaci: Pasolini..., s. $5-15$.

8 J. Мıкоєајеwsкi: Rzymska komedia... Fallaci podaje następujące szczegóły: „[sprawcy - K.M.T.] użyli jednak dwóch desek i kija. Na tych dwóch deskach był napis: »Butinelli A.« oraz »Via Idroscalo 93«. Doprawdy! Nie trzeba być Newtonem ani Sherlockiem Holmesem, by pojąć, że kiedy bije tylko jedna osoba, nie może używać trzech przedmiotów jednocześnie?!?" (O. Fallacr: Pasolini..., s. 93-94).

9 J. Мiкоєајеwsкi: Rzymska komedia... 
niepozostający bez związku z homoseksualizmem Pasoliniego oraz okolicznościami, w jakich doszło do jego zabójstwa. Stało się to bowiem w trakcie rzekomej próby gwałtu, jakiego miał on dopuścić się na opłaconym wcześniej młodym chłopcu, z którym przybył na wspomnianą plażę.

W trzeciej części utworu mamy do czynienia ze specyficzną grą słów:
i ziemia ta niebieska
nieziemsko piękna
we wszechświecie rana
karbunkuł w łonie
drogi mlecznej
pluje krwią i spermą

Ziemia, widziana z księżyca, zostaje porównana do błękitnego klejnotu, a „kosmiczna” perspektywa widzenia może również oddawać pośmiertną wędrówkę duszy bohatera ku niebu, skąd obserwuje planetę i zachwyca się jej pięknem. Jednocześnie karbunkuł w łonie, czyli czyrak, określony jest jako rana, wrzód na ciele niebieskim. Po jego przebiciu z wnętrza wydobywają się krew i sperma - może to być aluzja do natury samego Pasoliniego, zaszyfrowana informacja o preferencjach erotycznych artysty, który chętnie łączył przemoc fizyczną z doświadczeniem seksualnym ${ }^{10}$, jak również odniesienie do podłej natury ludzkiej - stąd planeta-karbunkuł, świadcząca o naszych głęboko skrywanych przed światem fascynacjach, zgoła nieludzkich.

Funkcja cytowanej przez poetę wypowiedzi Pasoliniego (której pochodzenia nie udało mi się do tej pory zidentyfikować), przywołanej w dalszej części utworu, jest ściśle powiązana z następującymi po niej słowami:

to ty Pier Paolo

powiedziałeś

„Człowiek widzi z daleka człowieka,

który zabija innego człowieka.

Jest świadkiem działania,

dystansuje się odeń..."

${ }^{10}$ Ibidem. 
jakiś człowiek

widział z daleka

innego człowieka

który zabijał ciebie

P III, 163-164

Fallaci w książce, stanowiącej zbiór tekstów napisanych w większości jeszcze w latach 70., wspomina o ewentualnych świadkach zdarzenia. Jednym z nich mógł być mężczyzna umawiający się - podobnie jak Pasolini - na schadzki w nadmorskich domkach blisko plaży w Ostii. Jej dalsze śledztwo wskazuje na to, że świadków, którzy pragnęli z obawy o swoje życie zataić prawdę o zdarzeniach tamtej nocy, mogło być więcej ${ }^{11}$.

Myślę, że należy tu wspomnieć o swoistym proroczym charakterze wypowiedzi udzielonych przez włoskiego reżysera w różnych wywiadach. Pasolini prawdopodobnie przeczuwał nadchodzącą śmierć. Niektórzy badacze jego życia i twórczości mówią również o „wyreżyserowaniu przez niego własnej śmierci"12. Winę za społeczny lincz, jakiemu poddano artystę, wielu przypisuje jemu samemu, skandalom, które wywoływał, a ostracyzm społeczny poczytuje się za naturalną konsekwencję jego działania. Za treści propagowane $\mathrm{w}$ dziełach reżysera wytoczono mu kilkadziesiąt procesów, a za pewnego rodzaju „kompromis” można uznać film Ewangelia według świętego Mateusza, w którym podjął tematykę chrześcijańską, łącząc ją z ideami marksistowskimi, co spotkało się z przychylną reakcją zarówno środowisk katolickich, jak i lewicowych ${ }^{13}$.

Niewątpliwie jednak różnego rodzaju naciski i notoryczne oskarżenia ukształtowały skomplikowaną psychikę artysty. Zgodnie z relacjami przyjaciół przedwczesna śmierć Pasoliniego była jedynie kwestią czasu, ponieważ on sam miał przejawiać skłonności samobójcze ${ }^{14}$. W jednym ze swoich dramatów, zatytułowanym Bestia

${ }^{11}$ Zob. O. Fallaci: Pasolini..., s. 47-48.

12 J. Miкоєаjewski: Rzymska komedia... Por. także N. Ginzburg: Od dawna żyt już w piekielnej, królewskiej samotności... Tłum. K. Kаватс. „Literatura na Świecie" 1976, nr 2, s. 26-30.

13 E. S巨̨Kоwsкa: Wielkie odkurzanie kina: Skandalista Pasolini. http://esensja.pl/ film/publicystyka/tekst.html?id=8406 [dostęp: 1.07.2020]. Por. także P. KLetowsкr: Ewangelia wedtug Piera Paola: „Wściekłość", "Zgromadzenie miłosne”, "Notatki z podroży do Palestyny", "Ewangelia wg św. Mateusza", "Ptaki i Ptaszyska”, "Ziemia widziana z Księżyca”, „Czym sa chmury”. W: Idem: Pier Paolo Pasolini: twórczość filmowa. Warszawa 2013, s. 133-172.

14 E. Sह̨KOWSKA: Wielkie odkurzanie kina... 
da stile, autor zamieścił takie oto, znamienne w kontekście swojej śmierci, słowa:

Jest święto. A ja w proteście chcę umrzeć z upokorzenia. Chcę, aby znaleźli mnie martwego, ze sterczącym penisem, ze spuszczonymi spodniami poplamionymi białą spermą, pośród zboża zabarwionego krwistoczerwoną posoką. I jestem przekonany, że to moje ostatnie przedstawienie - którego będę jedynym aktorem i jedynym widzem, w rzece, nad którą nikt nie przychodzi - nabierze znaczenia ${ }^{15}$.

Perspektywa obserwowania całego zdarzenia z punktu widzenia voyeura, tajemniczego świadka, przywołuje skojarzenia z tytułem filmu Ziemia widziana z księżyca, otwierającego listę dzieł Pasoliniego wyliczanych przez Różewicza. Kolejny wers to włoski tytuł filmu Chlew (Porcile), którego wymowa łączy w sobie wątki kanibalistyczne z krytyką konsumpcjonizmu, a jego bohater ostatecznie zostaje pożarty przez świnie, co można interpretować jako poetycką aluzję do morderstwa reżysera ${ }^{16}$.

Dalej rysuje się już wizja prawdopodobnego oprawcy Pasoliniego:

\author{
ledwie opierzony \\ żółtodziób \\ giovane di primo pelo \\ piekarczyk z palącymi oczami \\ Fornariny \\ P III, 164
}

Giuseppe Pelosi, który rzekomo zabił Pasoliniego w akcie obrony przed gwałtem, był siedemnastoletnim chłopcem, stąd określenia: „ledwie opierzony”, „żółtodziób”, czy wers w języku włoskim, w wolnym tłumaczeniu oznaczający "młodzieńca o pierwszym, dziewiczym zaroście”. „Piekarczyk” w guście Pasoliniego, wyglądem oczu przypominający kobietę z portretu La Fornarina Rafaela Santiego, „zwarł pośladki / odbytnicę raju”, co stanowi czytelną aluzję do obrony przed niechcianym aktem analnym ${ }^{17}$.

15 Ibidem.

${ }^{16}$ Więcej na temat Chlewu zob. P. KLetowski: Porcille mundi - o "Chlewie”. W: Pasolini: Tak pięknie jest śnić. Red. A. Pitrus. Kraków 2002, s. 74-84 oraz P. Kletowski: Filmowe testamenty Pasoliniego: Chlew, Salò, czyli 120 dni Sodomy. W: Idem: Pier Paolo Pasolini: twórczość filmowa. Warszawa 2013, s. 252-286.

${ }^{17}$ J. MiкoŁajewski: Rzymska komedia... Por. B. Kierc: Pisklę. W: Dorzecze Różewicza. Red. J. Stolarczyк. Wrocław 2011, s. 66. 
W następnej części wiersza został ukazany on jako jeden z bohaterów filmu Salò. „Niedorosły do powroza”, czyli zbyt młody, by ponieść konsekwencje czynu, o którym nie wiemy do końca, czy na pewno go popełnił, choć Pelosi przyjął na siebie całkowitą odpowiedzialność za zbrodnię i odbył wymierzoną karę. Przywołanie sceny spożywania ludzkich ekskrementów stanowi metaforę życia poza nawiasem, konsumowania tego, co świat „wydala” w postaci niestrawionych resztek.

Sam Pasolini w finale wiersza został ukazany jako stworzony na obraz i podobieństwo Boga. Wykonano na nim wyrok - i nigdy nie ujawniono tożsamości tego, kto tak naprawdę jest odpowiedzialny za to morderstwo. $Z$ zakończenia wiersza dowiadujemy się, że reżyser za swoje życie zostanie osądzony i rozliczony z niego na Sądzie Ostatecznym, gdzie spotka się z Bogiem, którego zawsze poszukiwał, o czym świadczy twórczość zanurzona w nurcie religijnym.

O zaskakującej, sakralizującej postać reżysera puencie utworu pisze Jacek Łukasiewicz:

Tu jednak nie ma mowy o papierowych trąbach, a obraz dźwignięty z gówna, porubstwa, upadku ma zakończenie pozytywne (jeśli to ironia, to wyrażane nią niedowierzanie utrzymane jest na wysokim poziomie wzniosłości) ${ }^{18}$.

Zakatrupiony, o którym Bogusław Kierc w tekście zatytułowanym Piskle pisze: "Ten wiersz, zbudowany z drastycznych paradoksów, coraz mi trudniej »oswoić«. Jest raną ironiczną. I rani"19, stanowi więc studium ofiary i kata, który najprawdopodobniej też padł ofiarą spisku lub został zwyczajnie wykorzystany przez osoby zamierzające pozbyć się reżysera. W życiu Pasoliniego można doszukiwać się pewnych aluzji do męczeństwa, na pewno jednak jego śmierci można również przypisać sens metaforyczny, podkreślając związki życia Pasoliniego z jego działalnością artystyczną. Niewątpliwie tak zrobił Różewicz, mistrzowsko posługując się zestawieniem wątków filmowych oraz biograficznych w poetyckiej relacji z miejsca zbrodni. Warto tutaj nadmienić, że Kierc dość odważnie sugeruje pewną więź pomiędzy Różewiczem i Pasolinim. Chodzi głównie o bliską poecie naturalistyczną formę wyrazu, dzięki której włoski reżyser "mógł być »sojusznikiem", który wdał się w bezkompromisową

18 J. ŁuKasiewicz: TR. Kraków 2012, s. 114.

19 B. Kierc: Pisklę..., s. 68. 
niezgodę z całym, dobrze się czującym, chlewem "postępowego« społeczeństwa" ${ }^{20}$.

Pomiędzy mistrzem z Friuli i poetą z Radomska istotnie rysuje się trudne do przeoczenia podobieństwo. Oriana Fallaci pisała o Pasolinim: „Byłeś tak bardzo religijny, Ty, który deklarowałeś, że jesteś ateistą. Tak bardzo potrzebowałeś absolutu, Ty, który miałeś obsesję na punkcie słowa człowieczeństwo"21. Zaledwie pół roku młodszy od Różewicza Pasolini, podobnie jak polski poeta, wywodził się $\mathrm{z}$ prowincji. Porzucił ją jednak na rzecz włoskiej stolicy w wyniku obyczajowego skandalu, a także - uciekając przed ojcem ${ }^{22}$. Silne piętno wywarła na nim również II wojna światowa i włoski faszyzm. Czytając wiersz Pasoliniego Do matki ${ }^{23}$, nie sposób wyzbyć się wrażenia, że miłość, którą darzył jedyną kobietę swojego życia, mogłaby okazać się tak bliska miłości i poświęceniu, jakie ofiarował matce poeta z Radomska. Biografie obu twórców pozostają w końcu w silnym związku z ich wybitnymi dziełami, nadając im osobisty charakter.

W wierszu Różewicza Pier Paolo Pasolini został ukazany jako ofiara własnej twórczości. Nieoczekiwanie stał się bohaterem swoich wielkich dzieł i, co podkreślił poeta, spotkał go los, jaki wielokrotnie przypisywał postaciom ze swoich dramatów i filmów. Przez lata bowiem historia życia i śmierci Pasoliniego oraz jego filmografia obrosły w specyficzną legendę, a w związku z tym stały się nierozłączną całością ${ }^{24}$. Mimo że film to zaledwie część obszernego dorobku Włocha, Różewicz utrwala rozpowszechniony wśród polskich odbiorców fragmentaryczny obraz Pasoliniego jako reżysera, choć był on przecież także poeta, prozaikiem, dramatopisarzem i eseistą ${ }^{25}$. Jak zauważa Serafino Murri:

20 Ibidem, s. 65.

${ }^{21}$ O. Fallaci: Pasolini..., s. 52-53. Por. A. Liszka: Ateista czyta Biblię. Pier Paolo Pasolini między religia a polityką. W: Religia a wspótczesne stosunki międzynarodowe. Red. B. BednarczyK, Z. Pasek, P. Stawiński. Kraków 2010, s. 273-284; I. Kolasińsка: Misja Jezusa według Piera Paolo Pasoliniego. W: Pasolini: Tak pięknie jest śnić..., s. 31-49.

22 Zob. A. Osmólska-Mętrak: Pier Paolo Pasolini: samotność proroka. https:// lente-magazyn.com/pier-paolo-pasolini-samotnosc-proroka/ [dostęp: 11.12.2020].

${ }^{23}$ P.P. PAsolini: Do matki. Tłum. A. SAmbor. "Literatura na Świecie” 1976, nr 2, s. 4.

${ }^{24}$ Por. S. KoŁos: Sens śmierci wedtug Pasoliniego. „Kino” 2004, nr 5.

${ }^{25}$ Por. M. Werner: Nieznany Pasolini. W: P.P. Pasolini: Po ludobójstwie. Eseje o języku, polityce i kinie. Tłum. A. Mętrak, I. Napiórkowska, M. Salwa. Warsza- 
Chęć prowokowania własną biografią i pragnienie utożsamiania się z własną twórczością dawały o sobie znać w trakcie całego życia Pasoliniego, nie sposób ich więc pominąć. Jednakże jego „sfera prywatna” była o wiele bardziej złożona, niż można by o tym wnosić nawet na podstawie wrodzonej mu skłonności do alegoryzowania siebie samego. Pasolini zginął wskutek prywatnego życia, jakie prowadził, przy czym zginął w chwili, gdy forsował granicę homoseksualizmu, który on sam dramatycznie przeżywał jako coś czysto osobistego. Przeżywał go mianowicie jako namiętność, jako transgresję, jako sublimację rodzinnych traum [...], ale także jako chęć poddania się próbie wykracza-

wa 2015, s. V-XIV. Swoistą przeciwwagę dla Zakatrupionego Różewicza stanowi utwór ks. Janusza Stanisława Pasierba z tomu Koziorożec, zatytułowany po prostu Pasolini, w którym postać Włocha zostaje uwznioślona. Utwór ten stanowi przede wszystkim hołd dla artysty i jest pozbawiony drastycznych szczegółów. Jest to protest przeciwko bezsensownej śmierci poety, którym przede wszystkim dla Pasierba był Pasolini:

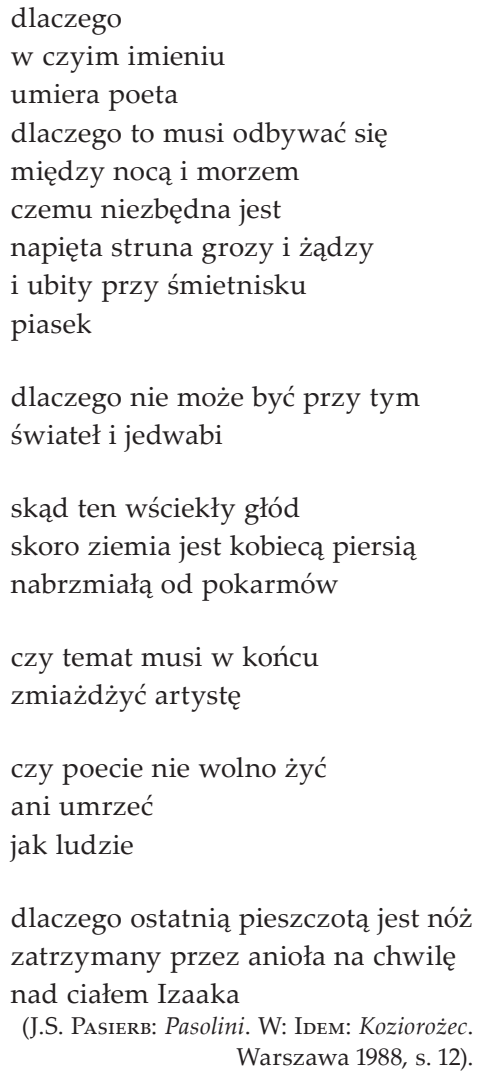


jącej poza jakiekolwiek schematy rządzące wizerunkiem publicznym ${ }^{26}$.

Drugim z przywoływanych przeze mnie wierszy o tematyce homoseksualnej jest Tate Gallery Shop, również podejmujący wątek schadzki z wyrazistym nawiązaniem malarskim ${ }^{27}$. „Umiejscowienie" kontekstowe homoseksualistów na aukcji eksponatów mieści się (być może niezamierzenie i nieoczekiwanie dla poety) w estetyce kampowej ${ }^{28}$. Delikatne rysy mężczyzny szukającego „okazji” przywodzą Różewiczowi na myśl twarz „świętego / ze słodkich obrazów prerafaelitów" (P III, 197).

Nasuwa się skądinąd pytanie, czy Różewicz miał szansę (i potrzebę) czytać Susan Sontag i czy tekst jej autorstwa był w jakikolwiek sposób inspiracją dla poety. Przetłumaczone Notatki o kampie ukazały się po raz pierwszy w numerze 9 „Literatury na Świecie” w 1979 roku, a więc przed napisaniem wiersza. W Notatkach zaś przeczytać możemy:

26 S. Murri: Portret artysty za życia. Pasolini, zaangażowanie $i$ "strach przed pożarciem". Tłum. M. Salwa. W: P.P. Pasolini: Po ludobójstwie. Eseje o języku, polityce i kinie..., s. 364-365.

27 Zob. R. CIEŚLAK: Oko poety. Gdańsk 1999, s. 99. O nawiązaniu w tym utworze do obrazów i biografii Francisa Bacona pisze niezwykle interesująco Katarzyna MŁynarczyk w tekście Antynomia niepokojów. Francis Bacon w świetle twórczości Tadeusza Różewicza. „Estetyka i Krytyka” 2009, nr 17/18 (2/2009-1/2010), s. 111-127. http://estetykaikrytyka.pl/art/17-18/eik_17-18_9.pdf [dostęp: 16.10.2017].

${ }^{28}$ Pasolini zarówno w życiu, jak i w twórczości również mógłby być postrzegany jako postać nie tylko kultowa, ale także kampowa. Perwersyjne sceny spożywania "gówna tego świata" w Salò (jak pisze w wierszu Różewicz, metaforycznie je interpretując) mogą przywodzić na myśl spektakularny, „obrzydliwie" kampowy film Różowe flamingi Johna Watersa (o kampie w wydaniu "trash” piszę dalej). Makabrycznym dopełnieniem zbrodni na Pasolinim wydają się też groteskowe okoliczności, w których przyjaciele reżysera dowiedzieli się o jego morderstwie: „Był piękny dzień, bardzo słoneczny. Usiedliśmy w barze Tre Scalini i zaczęliśmy rozmawiać o [Francisco - K.M.T.] Franco, który nie może umrzeć. Potem podszedł chłopak sprzedający »l’Unità« i powiedział [Giancarlowi - K.M.T.] Pajetcie: »Zamordowali Pasoliniego«. Powiedział to z uśmiechem, niemal jakby ogłaszał przegraną jakiejś drużyny piłkarskiej. [...] Na środku placu klaun w zielonych spodniach grał na fujarce. Grał, unosząc groteskowo nogi w zielonych spodniach, i ludzie się śmiali. [...] Ktoś roześmiał się głośniej, bo klaun machał teraz fujarką i śpiewał jakąś głupią piosenkę. Śpiewał: »Miłość umarła, przecinek, miłość umarła, kropka! Opłakuję więc ciebie, przecinku, opłakuję więc ciebie, kropko!«. Zrezygnowaliśmy z obiadu" (O. Fallacr: Pasolini..., s. 62). 
Kamp darzy szczególnym upodobaniem osoby wychudzone oraz osoby odbiegające od normy. Hermafrodyta jest na pewno jednym ze wzorców wrażliwości kampu. Przykłady: omdlewające, wysmukłe, bluszczowate postaci z malarstwa i poezji prerafaelitów [podkr. - K.M.T.]; chude, bezpłciowe ciała przedstawione na secesyjnych sztychach i plakatach lub oddane w reliefie na lampach i popielniczkach; upiorna pustka hermafrodyty kryjąca się za doskonałą pięknością Grety Garbo [... $]^{29}$.

O spotkaniu z Sontag w trakcie Międzynarodowego Kongresu Pisarzy w Dublinie Różewicz wspomina tylko w rozmowie z Adamem Czerniawskim i jest to bodajże jedyne miejsce, w którym pojawia się nazwisko amerykańskiej pisarki ${ }^{30}$.

Poeta kontrastuje w Tate Gallery Shop udosłownioną, „porcelanową" czy też "kryształową” kruchość życia homoseksualisty z Soho, igrającego ze śmiercią (wiersz opatrzony jest datą 1981 lata 80. XX wieku to okres, w którym uświadomiono sobie zagrożenie, jakie niesie ze sobą AIDS), z „ulicznym” wyglądem drugiego z opisywanych bohaterów:

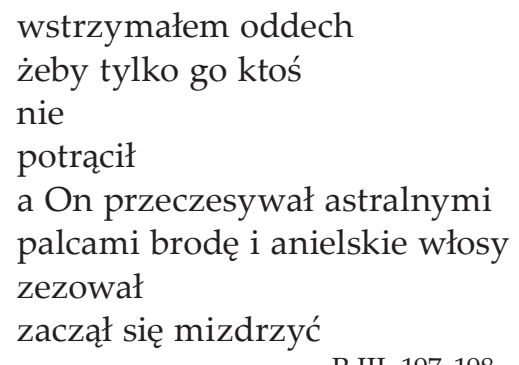

P III, 197-198

z kolei:

Ten drugi stał

pod kolumną

jak fałszywy święty Sebastian

pił z butelki piwo

miał pianę na ustach

29 S. Sontag: Notatki o kampie. Tłum. W. Wertenstein. W: Kamp. Antologia przekładów. Red. P. Czapliński, A. Mizerka. Kraków 2012, s. 53.

${ }^{30}$ O implozji poezji. Rozmawiał A. Czerniawski. W: Wbrew sobie. Rozmowy z Tadeuszem Różewiczem. Oprac. J. SтоLARсzүк. Wrocław 2011, s. 170-171. 


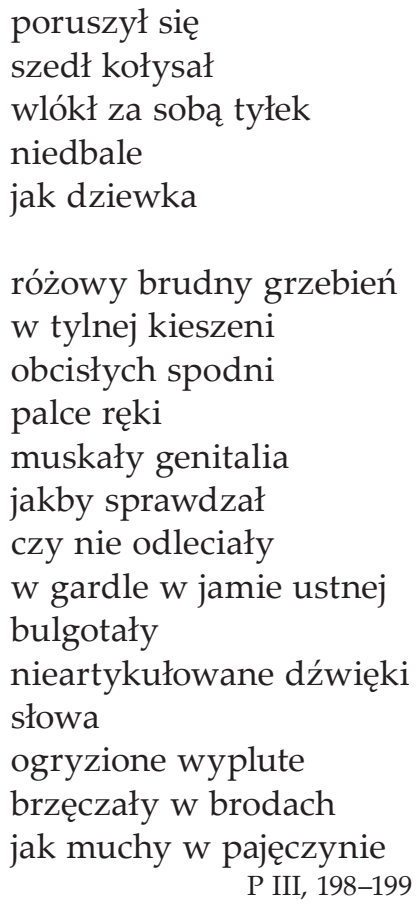

Przywoływany przez Różewicza obraz homoseksualistów utrwala stereotyp brudnej, zakażonej HIV cioty z marginesu, która z powodzeniem mogłaby się stać bohaterem jednej z powieści Michała Witkowskiego. Święty Sebastian zaś, jeden z najbardziej znanych męczenników chrześcijańskich, patron cierpiących na choroby zakaźne i orędownik w czasach epidemii, w środowisku homoseksualnym uchodzący za patrona gejów i lesbijek, postać inspirująca także twórczość Pasoliniego, zyskuje przydomek "fałszywy”, co potęguje wrażenie kampowego zderzenia sacrum z profanum. Opisywana dalej przez poetę „rozmowa kwiatów” zaowocowała gwałtownym spełnieniem, "mięsną" cielesnością nawiązującą do obrazów Francisa Bacona, znanego i bliskiego autorowi Niepokoju artysty-homoseksualisty:

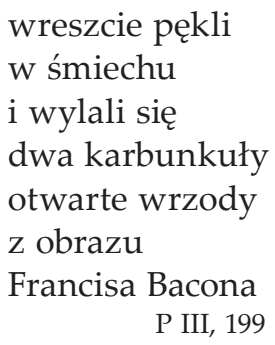


Kwiat stanowi tu ważny motyw erotyczny. Symbolika kwiatu łączy się nierozerwalnie z pięknem, jest również wyrazem miłości. Dodatkowo, dzięki swej budowie kwiaty utożsamiane są dosłownie $\mathrm{z}$ narządami płciowymi, zwłaszcza kobiecymi. Katarzyna Młynarczyk uruchamia tu szereg kontekstów malarskich w postaci obrazów znajdujących się w Tate Gallery, jak chociażby Josepha Mallorda Turnera, The Angel Standing in the Sun (1846) oraz Rzezi niewiniatek Nicolasa Poussina (1630), konstatując: „wydobywający się z »pieca ognistego / z grającej szafy« aluzyjny dźwięk odsyła nas [...] do tego, co święty Augustyn pisał o tym biblijnym wydarzeniu, określając zabite przez Heroda niemowlęta męczeńskimi kwiatami, przedwcześnie zmrożonymi zawiścią prześladowania" ${ }^{31}$. Jednak nie sposób pozostawić bez komentarza obecną także w tym wierszu dosadną fizjologię eksponującą przede wszystkim krańcowość istnienia. Jak pisze Łukasiewicz $\mathrm{w}$ książce zatytułowanej TR:

Niezwykle ważne w poezji TR [tak określa podmiot twórczości Różewicza Łukasiewicz - K.M.T.], w jego somatyzmie, są wydzieliny. Krew, ślina, marnotrawiona sperma, ale nade wszystko kał, rzadziej mocz - są wydzielinami złymi, podejrzanymi. Człowiek postrzegany jest (a może tylko bywa) jako napęczniały wrzód ${ }^{32}$.

Łącząc ściśle utwór Tate Gallery Shop także z biografią Bacona, a konkretnie odnosząc wiersz Różewicza bezpośrednio do związku malarza z Georgem Dyerem, Katarzyna Młynarczyk odsłania zarówno konteksty religijne, raz jeszcze podkreślające sakralizację bohaterów uosabiających świętego Sebastiana i Michała Archanioła, jak i wiarygodne nawiązania malarskie (George Dyer before a Mirror z 1968 roku czy Triptych, May-June 1973 autorstwa irlandzkiego malarza), świadczące o niebywałej erudycji autora $\mathrm{Na}$ powierzchni poematu $i$ w środku.

Erotyzm podszyty śmiercią ma we wspomnianych wierszach wyraźny wymiar somatyczny, tak jak w filmach Pasoliniego, w których wyuzdany hedonizm staje się narzędziem przemocy, tortur i skrajnego upokorzenia. Fascynacja Różewicza brzydotą i fizjologią, ciemną stroną natury ludzkiej, której poeta często przypisuje również seksualność, tym bardziej odnajduje wyraz w zainteresowaniu skomplikowaną osobowością homoseksualisty. Relacje homoerotyczne bowiem $\mathrm{w}$ stereotypowym odbiorze często pozbawione są

${ }^{31}$ Zob. K. MŁynarczyк: Antynomia niepokojów..., s. 114.

32 J. ŁUKASIEWICZ: TR..., s. 111. 
uczucia, zostają w mniemaniu ogółu „sfizjologizowane” i zezwierzęcone.

W dyskursach i praktykach kulturowych odmieńców wiele łączy z odpadami. Życie gejów, na przykład, często przedstawia się jako "zmarnowane" choćby dlatego, że odmawiając prokreacji marnują swoje nasienie, zrywają ciągłość rodu i zaprzepaszczają „ojcowski dar", co upodabnia ich nieco do biblijnego syna marnotrawnego, który „roztrwonił swój majątek, prowadząc rozwiązłe życie”33.

W książce zatytułowanej Oko poety Robert Cieślak podejmuje kwestię korespondencji poezji Tadeusza Różewicza ze sztukami wizualnymi. Choć skupia się przede wszystkim na odniesieniach malarskich, warto zwrócić uwagę na pokrewieństwo ulubionej przez poetę techniki kolażu (zaczerpniętej z malarstwa) i montażu filmowego (uobecnionego już w poezji awangardy, w której możemy dopatrywać się artystycznego rodowodu autora Kartoteki). Fragmentaryczność oraz charakterystyczna technika komponowania poetyckich obrazów, jak zauważa badacz, ma wiele wspólnego z montażem. Różewicz w oryginalny sposób „przycina” istniejące teksty kultury i „wprawia je” w ramy swoich dzieł ${ }^{34}$.

Znane „Różewiczowskie” tematy, takie jak kolażowość, fragmentaryczność czy konsumpcja i śmietnik, nabiorą nowego znaczenia, gdy spojrzymy na nie z perspektywy kampu w rozumieniu Sontag, która pisze:

Możliwe są tylko „fragmenty” [podkr. - K.M.T.]... Oczywiście, że obowiązują tu inne kryteria niż w kulturze tradycyjnej. Dzieło jest dobre nie dlatego, że jest dziełem skończonym, lecz dlatego, że odkrywa innego rodzaju prawdę o sytuacji ludzkiej, inne doświadczenie człowieczeństwa - krótko mówiąc - inną wrażliwość ${ }^{35}$.

Podobny efekt uzyskamy dzięki odniesieniu do tzw. trashu, czyli kampu niskiego, którego śmietnikowa poetyka przekroczenia społecznego tabu sytuuje się wbrew pozorom niedaleko poetyki autora Recyclingu. O „kampie śmieciowym” Chuck Kleinhans pisze,

${ }^{33}$ T. SiкоRa: Odmieńcy/śmieci..., s. 49.

${ }^{34}$ Zob. R. CIEŚLAK: Oko poety..., s. 61. Podobnie postępował Francis Bacon, poszukując inspiracji do swoich dzieł. Zob. D. KoŁacka: Francis Bacon - etymologia obrazów. „Kwartalnik Artystyczny” 2004, nr 1, s. 73-77.

35 S. SontaG: Notatki o kampie..., s. 61. 
że „wyrasta z odkrycia poczynionego przez gejów i inne mniejszości, że gust, czy też wrażliwość estetyczna to także społeczne konstrukty"36. W najsłynniejszym filmie reżysera Śmieciowej trylogii, Johna Watersa, zatytułowanym Różowe flamingi, mamy do czynienia $\mathrm{z}$ karnawałem obrzydzenia i prześciganiem się $\mathrm{w}$ celebrowaniu złego gustu, aż do punktu kulminacyjnego w scenie spożywania przez Divine świeżych psich odchodów ${ }^{37}$.

Zestawienie wzniosłości, religijności z obrzydliwą, mięsną wręcz cielesnością i konsumpcjonizmem, mieści się w kręgu zainteresowań artystycznych wszystkich trzech omawianych przeze mnie twórców, a punktem wspólnym wydaje się $\mathrm{w}$ szczególności motyw pasyjny. Różewicz, w przeciwieństwie do swojego przyjaciela, malarza Jerzego Nowosielskiego, fascynował się cyklem Ukrzyżowań Bacona. Swoisty ikonoklazm autora Niepokoju widać zwłaszcza w przypadku redukcji cierpiącego Chrystusa do strzępu mięsa wiszącego na krzyżu (poematy Róża oraz Francis Bacon czyli Diego Velázquez na fotelu dentystycznym). Ciało z obrazów Bacona i wierszy Różewicza to ciało $\mathrm{w}$ procesie, podlegające permanentnej transformacji. Rozchodzące się we wszystkich możliwych kierunkach ${ }^{38}$. W wierszu Ukrzyżowanie poeta Pasolini pisze o cielesności obnażonego, wystawionego na widok publiczny cierpiącego Chrystusa:

${ }^{36}$ C. Kleinhans: Wyjmowane z kosza. Kamp i polityka parodii. Tłum. K. SzewсzYк. W: Kamp. Antologia..., s. 415.

37 Zob. ibidem. Por. także: D. Bergman: Kamp. Tłum. A. Mizerka. W: Kamp. Antologia..., s. 183 oraz J. BräUnlein: Jak kultura Kampu dotarła do Niemiec. Tłum. A. Artwińska, K. Różańska. W: Kamp. Antologia..., s. 437-442.

38 Zob. R. CIEŚLAK: Oko poety..., s. 192-203. Cieślak zwraca uwagę na podobną do tej z Tate Gallery Shop scenę z poematu Róża, zbudowaną również na zasadzie kontrastu, w której „zapach piwa i moczu” oraz widok sepleniących prostytutek następują bezpośrednio po sprawozdawczym fragmencie opisującym otwarcie Isenheimer Altar: „W scenie tej symbolika Mistycznej Róży kontrastuje z pewnego rodzaju »śmietnikiem « cywilizacyjnym. Sytuacja ta ironicznie przenosi także dawną terapeutyczną funkcję malowidła [...] na grunt współczesności, w której obrębie powtórzenie drogi od Ukrzyżowania do Wniebowstąpienia jest już niewykonalne (ibidem, s. 200). Por. także A. Świeściak: Obrazy (po) śmierci poezji. W: Tadeusz Różewicz i obrazy. Red. A. Stankowska, M. ŚNiedziewska, M. Telicki. Poznań 2015, s. 105-117 oraz A. Stankowska: Ikonoklazm odwrócony. Tadeusz Różewicz w poszukiwaniu form "wewnętrznego obrazu”. W: Tadeusz Różewicz i obrazy..., s. 119-144. Szczególnie uderzające obrazy Chrystusa w twórczości Różewicza drobiazgowo analizuje w swojej książce, w rozdziale zatytułowanym Skatologiczny Chrystus, Tomasz Żuкowsкi. Zob. Idem: Obrazy Chrystusa w twórczości Aleksandra Wata i Tadeusza Różewicza. Warszawa 2013, s. 270-294. 
Będziemy wystawieni na krzyżu na szyderstwo oczu błyszczących dziką radością, wobec poniżeń i śmiechu obnażymy strumienie krwi od żeber do kolan, pokorni żałośni i drżący intelektem i pasją w grze serca które spala się własnym płomieniem, żeby dawać świadectwo zgorszeniu ${ }^{39}$.

Orbitująca gdzieś na marginesie twórczości Różewicza tematyka homoseksualna wpisuje się $\mathrm{w}$ tendencję postrzegania pragnienia homoerotycznego w kategoriach pokrewieństwa Erosa i Tanatosa ${ }^{40}$. Obecny, chociażby w poemacie Et in Arcadia ego, temat włoski staje się pretekstem do ukazania związków pomiędzy mityczną Arkadią i śmiercią ${ }^{41}$. Kwestii tej towarzyszy swego rodzaju wzniosłość, której nieco ironiczny wydźwięk podkreśla tragizm sytuacji. W wierszu Zakatrupiony jest to łączenie sensów oraz idei zawartych w filmografii Pasoliniego, celem wydobycia na powierzchnię kwintesencji jego biografii. W przypadku Tate Gallery Shop natomiast - świadome balansowanie ryzykanta na granicy życia i śmierci, swoisty dandyzm uwikłany w paradoks przyjemności i przedwczesnej śmierci.

Bliskie Pasoliniemu wydaje się wrażenie nieprzystawalności, kontestowanie społecznego monolitu i homogenicznej wspólnoty, która oparta jest na identyczności zacierającej tożsamość, a tym samym niosącej z sobą ryzyko powrotu do faszyzmu ${ }^{42}$. Odosobnieniu odmieńca sprzyja kamp rozumiany jako ciągłe przekraczanie kolejnych granic, nie skończony "styl”, lecz pewna nieuchwytna „stylistyczna dominanta" ${ }^{\prime 43}$. Pisząc o kulturze kampu w Niemczech, Jürgen Bräunlein używa trafnego porównania: „,kicz i kamp mają się trochę jak królik i zając. Wiecznie ze sobą mylone, w rzeczywistości różnią się

39 P.P. Pasolıni: Ukrzyżowanie. Tłum. J. Мıкоєајеwsкi. W: Pasolini: Tak pięknie jest śnić..., s. 113.

${ }^{40}$ Kwestię tę w odniesieniu do wczesnej twórczości J. Iwaszkiewicza rozważa Ryszard Przybylski. Por. Idem: Eros i Tanatos: proza Jarosława Iwaszkiewicza 1916-1938. Warszawa 1970.

${ }^{41}$ Por. R. Cieślak: Oko poety..., s. 138.

42 Por. P.P. Pasolini: Ludobójstwo. Tłum. A. Osmólska-Mętrak. W: Idem: Po ludobójstwie..., s. 287-292.

${ }^{43}$ Por. R. Pruszczyński: Kicz i kamp. Notatki z rozważań o terminologii. W: Lektury inności. Antologia. Red. M. Dąbrowski, R. Pruszczý́ski. Warszawa 2007, s. 263-271. 
tak bardzo, że nie można ich ze sobą krzyżować" ${ }^{\prime 4}$. Powszechnie znany i obecny $\mathrm{w}$ licznych dyskursach kicz jako sztuka reprodukowalna jest czymś egalitarnym, multiplikowalnym i masowym. Kamp jest $\mathrm{w}$ istocie zjawiskiem awangardowym, estetycznym zaakcentowaniem owej odrębności - ma subwersywny, teatralny charakter, wynikający z kondycji, w którą wtłoczeni zostali odmieńcy na przestrzeni wieków. Próba uczestnictwa w społeczeństwie na zasadach narzuconych przez heteronormatywną większość skutkuje ich odwróceniem od życia społecznego. Emancypacja ma więc wymiar antyspołeczny: nie chodzi przecież o asymilację poprzez unifikację, ale właśnie o wyjście z egalitarnej szafy, demonstrację odmienności ${ }^{45}$. Kamp w całej swojej rozciągłości i nieuchwytności istnieje właśnie po to, by tę inność drastycznie wyjaskrawić.

Jeśli nawet nawiązania "kampowe” u autora Niepokoju są zamierzone, to mogą bazować jedynie na pewnym ograniczonym wyobrażeniu kampu. Nie można zatem powiedzieć, że poeta jest kampowy, stosuje raczej zbliżoną do niego strategię dla uzyskania określonego efektu. Jako zdystansowany odbiorca kultury traktuje on tę estetykę jako surogat homoseksualnej subkultury, korzystając najprawdopodobniej z teoretycznych opracowań na temat kampu. Różewicz heteroseksualista nie jest nim w naturalny sposób przesiąknięty, powiela zatem gest Sontag: „zawłaszcza” kamp ${ }^{46}$. Nie „zabija go” jednak jak amerykańska eseistka, kamp nadal służy poecie do zobrazowania społecznego usytuowania gejów: z jednej strony twórców kultury, która trafia do mainstreamu uwielbianego przez „normalsów”, z drugiej - marginalnych wyrzutków społeczeństwa, którzy stoczyli się w kloaczny dół egzystencji. Różewicz, jak się zdaje, celowo pozostał zatem w estetyce adekwatnej do tożsamości wykreowanych przezeń bohaterów lirycznych. Co więcej, popartowa strategia bazująca przecież na kampie staje się skądinąd znakiem rozpoznawczym całej twórczości autora Recyclingu.

${ }^{44}$ J. BRÄUnlein: Jak kultura Kampu dotarła do Niemiec..., s. 435. Na temat rozumienia kiczu zob. H. Broch: Kilka uwag na temat kiczu i inne eseje. Tłum. D. BorKowsKa, J. Garewicz, R. Turczyn. Warszawa 1998.

45 Por. T. SiкоRa: To Come: Queer Desire and Social Flesh. „InterAlia” 2011, nr 6. http://interalia.org.pl/pl/artykuly/2011_6/03_to_come_queer_desire_and_social_ flesh.htm [dostęp: 11.12.2020].

${ }^{46}$ Nieporozumieniom wokół kampu, jego zawłaszczenia, a później przywrócenia homoseksualistom, poświęcono w literaturze naukowej i eseistyce wiele tekstów, których wybór zamieszczono w pierwszej części antologii kampu, zatytułowanej Do kogo należy kamp, gdzie znajduje się również przedruk cytowanego przeze mnie tekstu Susan Sontag. Zob. Kamp. Antologia..., s. 49-191. 
Ostatecznie przychodzi spytać o to, czy istotnie można sytuować dzieło Różewicza między kampem a estetyką brzydoty. Okazuje się bowiem, że dla poety, który czerpie niejako z obydwu konwencji, nie są to przeciwne bieguny praktyk ukazania homoseksualizmu, lecz koherentne elementy stanowiące o naznaczonej raną i cierpieniem homoseksualnej tożsamości. Autor Zakatrupionego i Tate Gallery Shop jawi się zatem przede wszystkim jako koneser kultury, którą konsumuje na wielką skalę, pieczołowicie osnuwając swoje teksty wokół biografii postaci niejednoznacznych, fascynujących jednak ze względu na pokrewne widzenie świata i darzonych przez niego szacunkiem. Znamienna dla Różewicza estetyka brzydoty, silnie związana z estetyką obrazów Bacona czy filmów Pasoliniego, staje się bowiem istotnym elementem przedstawienia $\mathrm{w}$ wierszach sytuacji i postaci, uwikłanych w rządzące nimi sprzeczności i dysonanse. Twórca pochyla się nad wspomnianymi bohaterami, kładąc nacisk na doniosłość i artyzm homoseksualnej śmierci (lub jej ryzyka), nie szczędząc jednak czytelnikom brutalnych szczegółów i fizjologicznych asocjacji. Żaden z tych obrazów poetyckich, mimo dobrej woli poety, nie jest do końca trafny, choć warto docenić fakt, że niejednokrotnie Różewicz stawał się "adwokatem mniejszości seksualnych" - jak pisze o nim Jan Marx ${ }^{47}$. Pewna zaś ironia, z jaką poeta ukazuje swoich homoseksualnych bohaterów, ma w sobie coś z ironii losu bohatera tragicznego. W sytuacji potrzasku śmierć staje się uwolnieniem, a pragnienie trwania $\mathrm{w}$ paradoksie - bezwstydną naiwnością.

\section{Bibliografia}

Bergman D.: Kamp. Tłum. A. Mizerka. W: Kamp. Antologia przekładów. Red. P. Czapliński, A. Mizerka. Kraków 2012, s. 179-191.

BräUnlein J.: Jak kultura Kampu dotarła do Niemiec. Tłum. A. Artwińska, K. Różańska. W: Kamp. Antologia przekładów. Red. P. Czapliński, A. Mizerka. Kraków 2012, s. 429-468.

Broch H.: Kilka uwag na temat kiczu i inne eseje. Tłum. D. Borkowska, J. Garewicz, R. Turczyn. Warszawa 1998.

${ }^{47}$ Autor w swojej książce zdecydowanie nie wyczerpuje potencjału, jaki ma w sobie tytułowe stwierdzenie. Por. J. Marx: Adwokat mniejszości seksualnych... W tym miejscu nie sposób nie przywołać Białego matżeństwa Różewicza i kontekstu w postaci krótkiego zapisu koncepcji sztuki opartej na Pogance Narcyzy Żmichowskiej, zatytułowanej Miłość lesbijska w romantycznym przebraniu. 
Cannavò A.: Oriana i Pier Paolo, przyjaźń niemożliwa. W: O. Fallaci: Pasolini. Niewygodny człowiek. Wstęp A. Cannavò. Tłum. J. Ugniewska. Warszawa 2018, s. 5-15.

Cieślak R.: Oko poety. Gdańsk 1999.

Fallaci O.: Pasolini. Niewygodny człowiek. Wstęp A. Cannavò. Tłum. J. UgniewSKA. Warszawa 2018.

Ginzburg N.: Od dawna żył już w piekielnej, królewskiej samotności... Tłum. K. KABATC. „Literatura na Świecie” 1976, nr 2, s. 27-30.

Kierc B.: Pisklę. W: Dorzecze Różewwicza. Red. J. Stolarczyк. Wrocław 2011, s. $65-68$.

Kleinhans C.: Wyjmowane z kosza. Kamp i polityka parodii. Tłum. K. SzewczyK. W: Kamp. Antologia przekładów. Red. P. Czapliński, A. Mizerka. Kraków 2012, s. $405-428$.

Kletowski P.: Pier Paolo Pasolini: twórczość filmowa. Warszawa 2013.

KLetowski P.: Porcille mundi - o „Chlewie”. W: Pasolini: Tak pięknie jest śnić. Red. A. Pitrus. Kraków 2002, s. 74-83.

Kolasińska I.: Misja Jezusa według Piera Paolo Pasoliniego. W: Pasolini: Tak pięknie jest śnić. Red. A. Pitrus. Kraków 2002, s. 31-49.

KoєAcka D.: Francis Bacon - etymologia obrazów. „Kwartalnik Artystyczny” 2004, nr 1, s. 72-77.

KoŁos S.: Sens śmierci według Pasoliniego. „Kino” 2004, nr 5, s. 57-60.

Liszka A.: Ateista czyta Biblię. Pier Paolo Pasolini między religia a polityka. W: Religia a wspótczesne stosunki międzynarodowe. Red. B. BednarczyK, Z. PaseK, P. StawIŃsKi. Kraków 2010, s. 273-284.

ŁukAsiewicz J.: TR. Kraków 2012.

Majchrowski Z.: Pisarz i jego sobowtór. Rekonesans. W: Autor, podmiot, bohater. Studia. Red. A. Martuszewska, J. SŁawiński. Wrocław 1983, s. 47-59.

Marx J.: Adwokat mniejszości seksualnych. W: Inem: Pomiędzy wieża Babel a wieża z kości słoniowej. O poezji Tadeusza Różewicza. Wrocław 2008, s. 37-83.

Miкоџлјеwsкi J.: Rzymska komedia, Czyściec, Pieśń V. Kronika nagłej śmierci. https:// wyborcza.pl/magazyn/1,124059,7332859,Rzymska_komedia__Czysciec_ Piesn_V.html [dostęp: 1.07.2020].

Meynarczyк K.: Antynomia niepokojów. Francis Bacon w świetle twórczości Tadeusza Różewicza. „Estetyka i Krytyka” 2009, nr 17/18 (2/2009-1/2010), s. 111-127. http://estetykaikrytyka.pl/art/17-18/eik_17-18_9.pd [dostęp: 16.10.2017].

Murri S.: Portret artysty za życia. Pasolini, zaangażowanie $i$ "strach przed pożarciem". Tłum. M. Salwa. W: P.P. Pasolini: Po ludobójstwie. Eseje o języku, polityce i kinie. Tłum. A. Mętrak, I. Napiórkowska, M. Salwa. Warszawa 2015, s. 363-388.

Osmólska-Mętrak A.: Pier Paolo Pasolini: samotność proroka. https://lente-maga zyn.com/pier-paolo-pasolini-samotnosc-proroka/ [dostęp: 11.12.2020].

Pasierb J.S.: Pasolini. W: Idem: Koziorożec. Warszawa 1988, s. 12.

Pasolini P.P.: Do matki. Tłum. A. Sambor. „Literatura na Świecie” 1976, nr 2, s. 4. Pasolini P.P.: Ludobójstwo. Tłum. A. Osmólska-Mętrak. W: P.P. Pasolini: Po ludobójstwie. Eseje o jezyku, polityce i kinie. Tłum. A. МętraK, I. NapiórкowsKa, M. Salwa. Warszawa 2015, s. 287-293. 
Pasolini P.P.: Ukrzyżowanie. Tłum. J. Mıкоєajewski. W: Pasolini: Tak pięknie jest śnić. Red. A. Pitrus. Kraków 2002, s. 112.

Pruszczyński R.: Kicz i kamp. Notatki z rozważań o terminologii. W: Lektury inności. Antologia. Red. M. Dąbrowski, R. Pruszczyński. Warszawa 2007, s. 263-271.

Przybylski R.: Eros i Tanatos: proza Jarosława Iwaszkiewicza 1916-1938. Warszawa 1970.

O implozji poezji. Rozmawiał A. Czerniawski. W: Wbrew sobie. Rozmowy z Tadeuszem Różewiczem. Oprac. J. Stolarczyк. Wrocław 2011, s. 169-172.

Różewicz T.: Utwory zebrane. T. 9: Poezja. 3. Wrocław 2006.

Sєૃкошsка E.: Wielkie odkurzanie kina: Skandalista Pasolini. http://esensja.pl/film/ publicystyka/tekst.html?id=8406 [dostęp: 1.07.2020].

SiкоRa T.: Odmieńcy/śmieci. „Kultura Współczesna” 2007, nr 4, s. 45-62.

Siкоra T.: To Come: Queer Desire and Social Flesh. „InterAlia” 2011, nr 6. http://inte ralia.org.pl/pl/artykuly/2011_6/03_to_come_queer_desire_and_social_flesh. htm [dostęp: 11.12.2020].

Sontag S.: Notatki o Kampie. Tłum. W. Wertenstein. W: Kamp. Antologia przekładów. Red. P. Czapliński, A. Mizerka. Kraków 2012, s. 49-67.

Stankowska A.: Ikonoklazm odwrócony. Tadeusz Różewicz w poszukiwaniu form "wewnętrznego obrazu". W: Tadeusz Różewicz i obrazy. Red. A. Sтаnкоwsкa, M. ŚniedziewsKa, M. Telicki. Poznań 2015, s. 119-144.

Świeściak A.: Obrazy (po) śmierci poezji. W: Tadeusz Różewicz i obrazy. Red. A. Stankowska, M. Śniedziewska, M. Telicki. Poznań 2015, s. 105-117.

Ubertowska A.: Tadeusz Różewicz a literatura niemiecka. Kraków 2001.

Werner M.: Nieznany Pasolini. W: P.P. Pasolini: Po ludobójstwie. Eseje o jezzyku, polityce i kinie. Tłum. A. Mętrak, I. Napiórkowska, M. Salwa. Warszawa 2015, s. V-XIV.

Żuкоwsкi T.: Obrazy Chrystusa w twórczości Aleksandra Wata i Tadeusza Różewicza. Warszawa 2013.

Żurowski S.: Skandalista. Pier Paolo Pasolini. http://art.webesteem.pl/14/pasolini. php [dostęp: 1.07.2020].

Krystian Maciej Tomala - doktorant w Zakładzie Historii Literatury Polskiej w Instytucie Filologii Polskiej na Uniwersytecie Gdańskim. Badacz form męskości w prozie, poezji i dramacie Tadeusza Różewicza, współorganizator konferencji naukowych: (Nie)męskość w tekstach kultury XIX-XXI wieku i (Nie)pokój w tekstach kultury XIX-XXI wieku oraz współredaktor obu tomów pokonferencyjnych (2019 i w druku).

e-mail: krystian.tomala@gmail.com 
